\title{
Serum immunoglobulin concentrations in preschool children measured by laser nephelometry: reference ranges for $\mathrm{IgG}, \mathrm{IgA}$, IgM
}

\author{
D ISAACS, ${ }^{*}$ DG ALTMAN, CE TIDMARSH, HB VALMAN, ADB WEBSTER
}

From the Departments of Paediatrics, Immunology, and Computing and Statistics, Northwick Park Hospital and Clinical Research Centre, Harrow, Middlesex HA1 3UJ

SUMMARY Serum immunoglobulin concentrations were determined on sera from 298 healthy children aged six months to six years using the Hyland laser nephelometer PDQ system. Agespecific $95 \%$ reference ranges for serum IgG, $\operatorname{IgA}$ and IgM are presented; considerable care has been taken to ensure statistical validity of the reference ranges. The wide range of values in children under two years suggest that measuring immunoglobulin concentrations in this age group is of little value in diagnosing immunodeficiency.

The determination of reference ranges for serum immunoglobulins in childhood has often been frustrated by the ethical difficulties of taking blood from healthy subjects. Many previous studies have therefore used sera from hospital in-patients who cannot legitimately be considered a normal population. In other studies too few subjects have been tested, leading to unreliable reference ranges. ${ }^{1-3}$ Other dubious methods include the assumption of a constant variability of $\log$ values. Adult serum immunoglobulin values are generally accepted as being lognormally distributed and several authors have assumed the same for immunoglobulin values in childhood. ${ }^{145}$ Under this assumption of a lognormal distribution reference ranges are calculated by taking the antilogarithms of the mean \pm 2 SD of the logarithms of the values. In some papers, however, arithmetic means and standard deviations were calculated from the raw data. ${ }^{26}$ Unless the data have a Gaussian (Normal) distribution, if necessary after logarithmic transformation, reference ranges obtained by these conventional statistical methods will be incorrect.

There are two controversial "clinical entities" in infants and young children which seem to be associated with low immunoglobulin concentrations. Firstly, it has been suggested that a low serum $\operatorname{IgA}$ in

\footnotetext{
*Present address: Academic Department of Child Health, Queen Elizabeth Hospital for Children, Hackney Road, London E2 8PS.
}

Accepted for publication 3 May 1983 infants from atopic families predisposes to infantile eczema and possibly other allergic phenomena. ${ }^{7}$ Secondly, there is confusion about the definition of "transient" hypogammaglobulinaemia of infancy. Some workers define this condition by a "lower than normal" serum IgG, despite the finding that many ofthese children can make normal amounts of functional IgG antibody. ${ }^{8}$ The aim of the present study was to produce carefully validated reference ranges for serum $\operatorname{IgG}, \operatorname{IgA}$ and $\operatorname{IgM}$ and to question whether these concentrations are likely to be of use in the diagnosis of antibody deficiency in young children.

\section{STUDY POPULATION}

One of us (DI) attended infant welfare clinics and school medicals in the Harrow area. The primary purpose of the study was to obtain information on the antibody response to pertussis vaccine in children (to be published elsewhere). The study was approved by the Harrow District Ethical Committee. The nature of the research was fully explained to the parents and permission was sought to obtain a single sample of venous blood from their child. Permission was also obtained from children over three years of age, and when possible also in younger children. A surprising number agreed to give blood "to help other children." Children with a history of recurrent infection, allergic disease or any intercurrent infection were excluded.

Venous blood ( $2 \mathrm{ml}$ ) was obtained using a size 23 butterfly needle (Venisystem, Abbott Ireland Ltd, 

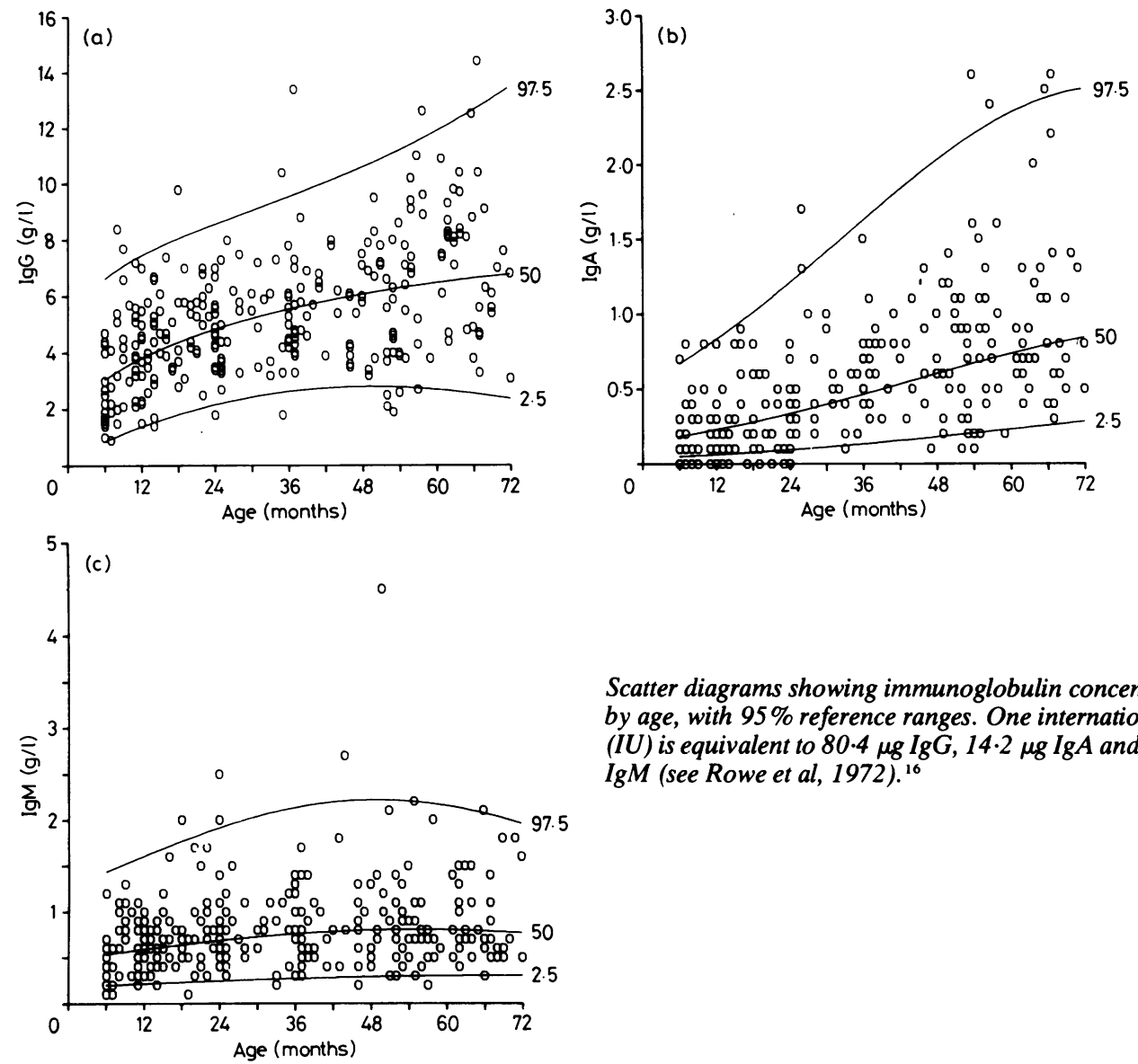

Scatter diagrams showing immunoglobulin concentrations by age, with $95 \%$ reference ranges. One international unit (IU) is equivalent to $80.4 \mu \mathrm{g} \operatorname{IgG}, 14.2 \mu \mathrm{g} \operatorname{IgA}$ and $8.47 \mu \mathrm{g}$ IgM (see Rowe et al, 1972). ${ }^{16}$

Sligo). A total of 298 specimens were collected (141 boys and 157 girls) and there were at least 30 serum specimens for each age range, 6-9 months; 10-12 months; 13-18 months; 18-24 months; 25-36 months; $37-48$ months; $49-60$ months and $61-72$ months. There were 224 of European origin, 72 were Asian and two were West Indian.

\section{Material and methods}

All sera were analysed using a Hyland laser nephelometer PDQ system. ${ }^{9}$ The standard serum used was calibrated from the WHO standard human serum (Reference Code No 67/97) ${ }^{16}$. The sera were stored at $+4^{\circ} \mathrm{C}$ for up to 4 days before being tested; freezing and thawing were avoided as they may alter immunoglobulin concentrations. ${ }^{10}$ Serum IgA concentrations under $0.1 \mathrm{~g} / 1$ were recorded as $<0.1 \mathrm{~g} / 1$, since this is the lower limit of accurate detection of IgA by nephelometry. However, sera from children with nephelometric serum $\operatorname{IgA}<0 \cdot 1 \mathrm{~g} / 1$ were also

tested by a double antibody radioimmunoassay previously described ${ }^{11}$ and all such sera were found to have an $\operatorname{IgA}>0.03 \mathrm{~g} / 1$ by this method.

\section{STATISTICAL METHODS}

There are two main desirable properties of reference ranges. Firstly, they should be a valid reflection of the raw data, and secondly specific reference ranges should change smoothly with age. Very few studies have demonstrated the correctness of their statistical methods. Also, most published reference ranges are implausibly erratic, where a smoothlychanging range is much more credible. In the present study great care was taken to achieve valid and plausible reference ranges, although the end result must still be largely dependent upon the representativeness of the children in the study. The general strategy adopted here is briefly summarised:

(i) The data were transformed so that the transformed data values were reasonably Normally distributed at all ages. This was achieved not 
by considering statistical significance alone, but by finding the transformation for which the transformed values were nearest to a Normal distribution, using Shapiro and Wilk's W test. ${ }^{12}$

(ii) A polynomial regression model was fitted to the transformed data.

(iii) Another polynomial regression model was fitted to the standard deviations of the residuals about the previous regression. For this purpose the age range was subdivided into eight. (Note that step (i) does not imply that the transformed variables were equally variable at all ages.)

(iv) The reference range was calculated as

$$
f_{1} \text { (age) } \pm 1.96 f_{2} \text { (age) }
$$

where $f_{1}$ and $f_{2}$ are the fitted functions of age derived in steps (ii) and (iii), and these values were backtransformed as appropriate.

(v) The goodness-of-fit of the models was carefully assessed.

Steps (ii) to (iv) were repeated until a satisfactory result was obtained.

Values of serum $\operatorname{IgA}$ which were recorded as $<0 \cdot 1$ $\mathrm{g} / \mathrm{l}$ necessitated the use of statistical estimation procedures appropriate for censored data.

\section{Results}

The standard deviation of the nephelometric method, as determined in 19 replicates of a normal serum, was between $7-10 \%$ of the mean for all three immunoglobulin classes. Logarithmic transformation was found to be highly appropriate for both $\operatorname{IgA}$ and IgM; but for IgG the square root transformation was superior. The equations fitted to the means and standard deviations, which are given in the Appendix, were combined as previously described and appropriately back-transformed to give $95 \%$ reference ranges.

The raw data for the serum immunoglobulins and the $95 \%$ reference ranges are shown in Figs. a-c. No difference was observed between boys and girls, nor between European and Asian children so the reference ranges were derived from all the data. There were a large number of healthy children in the first two years of life with serum $\operatorname{IgA}$ concentrations below $0.1 \mathrm{~g} / \mathrm{l}$. Fig. (b) shows that the lower limit of the reference range for $\operatorname{IgA}$ is below $0 \cdot 1 \mathrm{~g} / \mathrm{l}$ until 26 months of age.

\section{Discussion}

We have shown that serum immunoglobulin values in children are not all lognormally distributed and have produced smooth age-specific reference ranges for $\operatorname{IgG}, \operatorname{IgA}$ and $\operatorname{IgM}$. The care taken in this study is important because many of the previously reported ranges are either of dubious validity because of the statistical methods used or the small number of subjects tested in each age range studied, or are less than ideal because no smoothing was performed. The very low concentrations of serum IgG found in apparently healthy children in the first year of life calls into question the usefulness of measuring such concentrations in children with suspected antibody deficiency. Tiller and Buckley ${ }^{8}$ have recently suggested that transient hypogammaglobulinaemia of infancy is extremely uncommon, since they found only 11 cases amongst 10000 whose sera were sent for immunoglobulin studies over a 12-year period. Their reference range is based on sera from 201 normal individuals, but only about 10 subjects were tested in each three-month age range from $0-2 \mathrm{yr}$; and there were less than 10 subjects in each subsequent year up to the age of $5 \mathrm{yr} .{ }^{4}$ These results have been questioned by Siegel and colleagues ${ }^{13}$ who studied $T$ helper activity in 17 children with transient hypogammaglobulinaemia of infancy. One of their criteria for the diagnosis of transient hypogammaglobulinaemia was a serum IgG concentration three or more standard deviations below the geometric mean for the patient's age; but again their reference range was based on sera from less than $\mathbf{1 5}$ healthy subjects in each year. Although it is not strictly legitimate to compare results from two different laboratories, it is interesting that only 8 of 17 abnormal serum IgG values in their study fall below our $95 \%$ reference range.

We also found that our lower limit of normal for serum IgA was considerably lower than is generally accepted. Although laser nephelometry in our hands was unable to detect serum IgA concentrations under $0 \cdot 1 \mathrm{~g} / \mathrm{l}$, this has been allowed for in the statistical analysis and there were too few such concentrations to have a great effect on our reference range. Much of the present controversy over the clinical significance of low serum IgA in childhood is based on data analysed on the assumption that the data were Normally distributed. Using our rigorously derived reference ranges, it appears unlikely that low $\operatorname{IgA}$ in infancy will show a significant association with atopic eczema' cow's milk allergy, ${ }^{14}$ or febrile convulsions. ${ }^{15}$

This study demonstrates that the measurement of serum immunoglobulins is of limited value in the diagnosis of antibody deficiency in the first two years of life. We clearly need different criteria for the diagnosis of antibody deficiency, and a better test might be to measure specific antibody responses after test immunisation. 


\section{Appendix}

The polynomial regressions fitted to the age-specific mean and standard deviation of the transformed serum immunoglobulin values are given below. Note that age is in months.

$\log \operatorname{Ig} A$

Mean $=-1.92+0.03975$ Age $-0.0002155 \mathrm{Age}^{2}$

$\mathrm{SD}=0.658+0.0003166$ Age -0.00002374 Age $^{2}$

Square root of $\mathrm{IgG}$

Mean $=1 \cdot 16+0.2715$ Age -0.01195 Age

$\mathrm{SD}=0.45-0.00550$ Age $+0.0000945 \mathrm{Age}^{2}$

$\log \operatorname{Ig} M$

Mean $=-0.74+0.01899$ Age -0.0001728 Age $^{2}$

$\mathrm{SD}=0.494+0.002064$ Age -0.00003191

$\mathrm{Age}^{2}$

The $95 \%$ reference ranges were calculated by taking the age-specific values of mean $\pm 1.96 \mathrm{SD}$ and back-transforming as appropriate.

We would like to thank the staff of the infant welfare and school clinics who helped us in obtaining serum samples. We were also grateful to the staff of the Haematology Department of Northwick Park Hospital for help in measuring the immunoglobulin concentrations.

\section{References}

' Allansmith M. Development of immunity. In: Falkner F, ed. Human development. Philadelphia: WB Saunders, 1966: $582-601$.

${ }^{2}$ West CD, Hong R, Holland NG. Immunoglobulin levels from the newborn period to adulthood and in immunoglobulin deficiency states. J Clin Invest 1962;41:2054-64.
${ }^{3}$ Saarinen VM, Pelkonen P, Slimes MA. Serum immunoglobulin A in healthy infants. An accelerated post-natal increase in formula-fed compared to breast fed infants. J Pediatr 1979;95:410-4.

^ Buckley RH, Dees SC, O'Fallon WM. Serum immunoglobulins: I. Levels in normal children and in uncomplicated childhood allergy. Pediatrics 1968;41:600-11.

${ }^{5}$ Hobbs JR. Simplified radial immunodiffusion. ACP Broadsheet 68, 1970.

' Collins-Williams C, Tleachyk SJ, Toft B, Moscarello M. Quantitative immunoglobulin levels (IgG, IgA, and IgM) in children. Int Arch Allergy 1967;31:94-103.

${ }^{7}$ Soothill JF, Stokes CR, Turner MW, Norman AP, Taylor B. Predisposing factors and the development of reaginic allergy in infancy. Clin Allergy 1976;6:305-19.

8 Tiller TL, Buckley RH. Transient hypogammaglobulinaemia of infancy. Review of the literature, clinical and immunologic features of 11 new cases, and long-term follow-up. $J$ Pediatr 1978;92:347-53.

9 Whicher JT, Perry DE, Hobbs JR. An evaluation of the Hyland laser nephelometer PDQ system for the measurement of immunoglobulins. Ann Clin Biochem 1978;15:77-85.

${ }^{10}$ Tidmarsh CE. Problems associated with the preparation of an immunoglobulin reference range by laser nephelometry. Brunel University: M Phil thesis, 1980.

"DeGast GC, Platts-Mills TAE. Functional studies on lymphocytes in adult human bone marrow. II. Isolated surface IgM positive cells. J Immunol 1979;122:285-90.

${ }_{12}$ Royston JP. An extension of Shapiro and Wilk's W test for normality to large samples. Appl Statist 1982;31:115-24.

${ }^{13}$ Siegel RL, Issekutz T, Schwaber J, Rosen FS, Geha RS. Deficiency of $\mathrm{T}$ helper cells in transient hypogammaglobulinaemia of infancy. $N$ Engl J Med 1981;305:1307-13.

${ }^{14}$ Harrison M, Kirby A, Walker-Smith JA, France NE, Wood CBS. Cow's milk protein intolerance: a possible association with gastroenteritis, lactose intolerance and $\operatorname{IgA}$ deficiency. $\mathrm{Br}$ Med J 1976;i:1501-4.

${ }^{15}$ Lewis H, Valman HB, Webster ADB, Tyrrell DAJ. Viruses in febrile convulsions. Lancet 1980;i:150.

${ }^{16}$ Rowe DS, Grab B, Anderson SG. An international reference preparation for human serum immunoglobulins $\mathbf{G}, \mathbf{A}$ and $\mathbf{M}$ : content of immunoglobulins by weight. Bull WHO 1972;46:67-79.

Requests for reprints to: Dr ADB Webster, Division of Immunological Medicine, Clinical Research Centre, Watford Road, Harrow, Middlesex HA1 3UJ, England. 